\title{
Making Sense of Life Without the Possibility of Parole
}

$\mathrm{O}^{\mathrm{n}}$ $\mathrm{n}$ the inside, within the first layer of ramparts that envelop the greywalled penal structure, sits a lethal electrified fence that is arguably more gruesome and deadly for prisoners than the lofty gun towers that dot its foreboding perimeter. Within the second layer of divisions is a labyrinth of restrictive barriers and brickwork that snake their way toward a larger maze of pavement and chain-link fences that house a virtual world of hardened concrete and fortified steel. A purgatorial home for most prisoners before they are released back into society, this is also your average house of hopelessness for the fast-increasing population of men, women and children forever sentenced to life without the possibility of parole (Nellis and King, 2009; see also Appleton and Grover, 2007).

In 2008, 41,095 people were serving life without the possibility of parole. The extended influx of life without the possibility of parole sentences is reflected in its rapid growth: In 1992 there were 12,453 people serving life without the possibility of parole sentences. Just sixteen years later that number tripled (Nellis and King, 2009, p. 4). Why? That is the question every American citizen should be asking. Senator Jim Webb (2009, p. 4) of Virginia questioned America's penchant for disproportionately locking up its own citizens, stating: "Either we are the most evil people on earth, or we are doing something very wrong".

Nevertheless, this elaborate bulwark of impediments is designed to protect society from the varied lot of denizens to such hell houses for the crimes they've committed against society. From the non-violent to the extremely violent, their attitudes, temperament and dangerousness to society is about as diverse as the offenses they have committed.

It is society's hope that while inside, offenders will repent and reform themselves; that they will conform to societal standards of comportment and become productive, taxpaying members of the law-abiding community. Unfortunately, the vast majority of penal institutions fail miserably at their calling. Indeed, it is rather a unique aberration for most American 'corrections' and 'rehabilitation' systems to claim even a reasonable paroleto-success rate. California, by all accounts, has the very worst recidivism rate at nearly 70 percent (CDCR, 2011).

So the failing system and the weary citizenry engage in a vicious and destructive cycle, with the citizens growing evermore angry at the persistent recidivism rates and the malignant continuum of repeat offending. The 
hapless prisoner is caught somewhere in the middle (Zimring et al., 2001). The truth is that the process of programming, progression and rehabilitation hinge on the guidance and tools made available to the prisoner while incarcerated. If nothing is offered, or made available in these steel-barred dungeons of deprivation, then the prisoner has little more to do than be idle.

Not surprisingly, California also has one of the most extensive populations of prisoners sentenced under life without the possibility of parole $(3,679)$, along with Florida $(6,424)$, Louisiana $(4,161)$ and Pennsylvania $(4,434)$ (Nellis and King, 2009, p. 3). The cause of at least a portion of the growth in life without the possibility of parole sentences is the failure of the penal institutions to rehabilitate prisoners. Some life without candidates graduate to society's level of so-called incorrigibility by repeat offending, gradually growing more brazen. Yet, while previously in the "system" they were systematically neglected in being taught new skills, having a new mindset instilled and being provided real and tangible post-release support (ibid).

It cannot be overstated how important it is for institutions to steer prisoners away from idle time. But in reality, prisons are too often idle places where little if any rehabilitation is offered. Personally, I find this interesting because studies have shown that for every $\$ 1.00$ spent on rehabilitation, a projected $\$ 2.50$ is saved in prevention (California Rehabilitation Oversight Board, 2011). Indeed, the only difference between the criminal mind and the law-abiding mind is the thinking, and it is likely that the person will be rehabilitated.

Another contributing factor to the growth of life without the possibility of parole sentences is that too often prisoners with non-life sentences are released without any meaningful job training or the educational tools necessary to succeed. When they inevitably fail, including the very few who commit the more notorious and tragic offences, the news media recycles the stories as if such cases were the norm. The more gruesome the crime, the more repetitive and sensational the coverage. Understandably, the public becomes infuriated. The public demands harsher sentences; society wants "life to mean life" (Nellis and King, 2009, p. 3). Consequently, the public's ire is then exploited by politicians seeking office or trying to secure an incumbency seat. Society is often bewitched by the deception that such crimes of notoriety are the rule, not the exception. Instead of holding wardens accountable, much like teachers are held accountable for their lack of success in the classroom (Torres, 2010), society misdirects its anger on the unequipped prisoner. 
Another factor exacerbating this paradigm are the policies behind the recidivism. In most cases a parolee does not have to commit a crime to be sent back to prison. A parole violation - basically breaking some minor rule - can be grounds for a person to be sent back to prison. California, in particular, has been criticized for re-imprisoning parolees for technicalities as minor as being in association with another ex-felon - even family members. So officials hurl the parolee back into a prison overflowing with full-fledged felons. ${ }^{1}$

Others have been returned for failing a drug test, which might be acceptable if they were offered some type of drug rehab once back inside. But this is not the case. For the vast majority of parolees, such policies severely challenge and threaten their long-term stability on the outside as they strive to re-integrate into society. Yet, absent a life sentence they are mandated to be released. It is a violent vortex that takes its ever-depleting toll. Failure at the bottom of the system extends itself above. Lifers, a rarely released segment of the population, are frequently assumed to have the same failure rates and are often denied any chance at parole to prove otherwise.

In the past twenty years America's punitive structures have become so out of sync that the U.S. stands shamefully unique among industrialized nations in its regressive approach to sentencing via mandatory guidelines. These inhumane guidelines judge crimes by cold, coded and set formulas that ignore the person and their behaviour. The individual's history is ignored, any symptoms that led to the offense are ignored - and thus many remedies for preventing crime; tracking patterns, or tailoring a treatment for the offender are lost. In earnest, any objective review of America's draconian sentencing statutes would reveal a mishmash of punishments that lack any rhyme or reason. None of it makes any sense.

Life without the possibility of parole is nearly unthinkable in other civilized nations. Other countries, such as Japan, Italy, Mexico and Peru, among many others, limit incarceration at thirty years (USA Today, 2010). When life without the possibility of parole is applied in other industrialized nations, it is used sparingly.

During a February 2010 address to lawyers in Los Angeles, California, U.S. Supreme Court Justice Anthony M. Kennedy expressed his dismay at the politicizing of prisons in California stating that U.S. sentencing is eight times longer than in European courts (C. Williams, 2010). This brings to the fore another prudent question: is America's prevalent use of an absolute 
sentence such as life without the possibility of parole really necessary? Particularly as pertains to your average first-time offenders.

Without giving any mind as to whether these people are redeemable and without at least screening them through parole boards during the course of their incarceration, how would anyone know if such offenders are salvageable? To just throw people away without giving thought to human possibilities is about as arbitrary as anyone can get. On the other hand, I can already hear the professional victims' rights people saying something cynical like: "Well, these murderers didn't give their victims any such consideration". And perhaps that may be so, but is not that the difference between a criminal mind and a civil society? Should the goal not be to reform the criminal mind? That is precisely why society must do everything within its power to rehabilitate the minds of its miscreants. More to the point, America's merciless penchant for throwing people away shows a blatant disregard for human life that is eerily similar to sociopathic criminal thinking.

Truth be told, there is no evidence-based foundation to America's sentencing patterns. In reality, it is not necessarily how much time an offender does, but the quality of one's incarceration that can determine if the person is redeemable or not. ${ }^{2}$ Americans need to decide what they want from prisons. If Americans truly want to prevent crime, and utilize prisons to "correct" and "rehabilitate" then they must invest in the human beings that they now so apathetically warehouse. Nevertheless, in general, if punishment, and punishment only, is the goal, then America is on the right path, but the consequences of this current vain and short-sighted approach is to punish and release the vast majority of prisoners no better, and perhaps worse, than when they entered. Any people so sadistic that they would rather punish than rehabilitate needs to first rehabilitate themselves.

Still, American television constantly harps on second chances. Not for the errant rich and famous, of course, but for these faceless souls, the poor and undeserved, the message seems to be the complete opposite. This fact is frequently lost in the fog of demagoguery that competes to see who can be tougher on crime, in lieu of being smarter, wasting valuable prison space and scarce financial resources. This is hard to make sense of.

The politically motivated "tough-on-crime" pursuit, in the past three decades, has proven itself an annual $\$ 60$ billion farce and failure, as indicated by unacceptable recidivism rates across the land. Still, life sentences have more than tripled since 1992 (Nellis and King, 2009, p. 2). States with the 
largest life without the possibility of parole populations corner the market with an average of one in six of their prisoners sentenced to these eternal sentences (ibid, pp. 5-9).

In many cases, life sentences with the possibility of parole are so frequently served beyond their minimum eligibility dates that they become, for all intents and purposes, life without the possibility of parole. In the federal trial regarding California's severe overcrowding problems, Justice Thelton Henderson criticized the corrections system for routinely denying prisoners' parole despite their having fulfilled all the requirements necessary to meet suitability. ${ }^{3}$ Alexander Cockburn was absolutely correct in the article, "Dead Souls", saying: "What [life without the possibility of parole] means is that for the convicted murderers who would otherwise get life with parole, often at very young ages, and who redeem themselves through rehabilitative efforts, even the remotest possibility of release will never become available" (Cockburn, 2009). This is also hard to make sense of.

One of the early foundations of mandatory sentences in America was the passage of the Rockefeller Drug Laws. Enacted in 1973 by the New York Legislature to counter the drug epidemic, harsh-draconian mandatory sentences were imposed to stem and deter black market drug sales. The selling point of the law was to go after drug kingpins, but like California's Three Strikes Law, priorities got turned upside down and it was the petty offender that became the focus of arrests. The Rockefeller law preyed on street peddlers caught selling two to four ounces; The Three Strikes Law primarily nets small time offenders: drug possession, petty retail theft such as diapers and chewing gum. Under both state laws life sentences were the consequence for these minor crimes (Families to Amend California Three Strikes Law, 2011). However, after a stirring grassroots battle against the "tough-on-crime" rhetoric, the Rockefeller Drug Laws were scaled back some, saving the taxpayers untold billions and, at least to some degree, reserving limited cell space for the more dangerous felons (Papa, 2010).

Like most judges who frown on removing judicial discretion from justices through mandatory sentences, U.S. Supreme Court Justice Kennedy criticized California's most influential union, the California Correctional Peace Officers Association (CCPOA) for their role in pushing controversial laws like three strikes, characterizing their prison peddling tactics as "sick" (New York Times, 2010). Under California's version of the Three Strikes Law, an individual convicted of a misdemeanour can be sentenced to 
twenty-five-years to life, the same punishment for murder in the Golden State.

One of the more widely publicized instances of a three strikes injustice was the case of Gary Ewing, who was sentenced to twenty five years to life for shoplifting three golf clubs from a Pro-golf shop (ibid). This is the epitome of what Confucius would call "using a cannon to kill a mosquito".

To be fair, the CCPOA is not alone in exploiting prisoners to bolster job security. Many states, such as New York, have relied on prisons for employment (Moore, 2009). As factory jobs were shipped overseas with little discouragement from lawmakers, a quasi neo-slavery system of prisoners took hold. "Build them and they will come", goes the saying. Tweak the policies that lead to prison, toss in a "no-tolerance" scheme for children of public education as we have seen across the board, and after they are built and filled with taxpayer funds, the American dream - for the privileged - will materialize. Longer sentences with more social snares to catch their prey make for a rather secure financial windfall for prison guards despite a consistent decrease in crime in every state, including those with less punitive measures (Johnson, 2010).

Another incentive for local communities to host prisons is a keepsake from the slavery-era Census count: the infamous three-fifths of a person rule. Here, prisoners counted in modern Census undertakings augment the population for the local community. The mechanics of this work like so: Joe Average gets himself in trouble in his own community; the community where he was raised and perhaps paid taxes all of his life. Once found guilty, he is sent to prison, usually in some rural remote place. During the Census Mr. Average is counted in his new community, which augments the local population and as a result, the local community gets more revenue and an increase in political representation. However, Mr. Average cannot vote, benefit from the extra funds, nor does his community of origin - just as it was during the slavery era. The incentive for such exploitation is obvious under such rules. It is for these reasons, I surmise, that correctional worker unions do what they do: promote the growth of prisons for the wellbeing of their membership. Such benefits also help the powers that be sell the idea of prison construction in new communities.

This writer happens to be a Mr. Average, serving a life without the possibility of parole sentence. In any case, it was a dark summer night in 1989, I was twenty-three years of age. I was driving my pregnant, twenty- 
two-year-old wife and two-year-old daughter home. On the way I had witlessly planned to make a drug drop, which culminated into the robbery of me and my wife. My wife resisted and was mortally shot. I refused to deal with the police because of my culpability in the drug deal. A few months later I was charged with the murder of my beloved wife. We owned a life insurance policy, as most responsible couples do, and the police readily declared financial gain as my motive. In addition, I was also charged with lying-in-wait, which, like the financial gain charge, is a special circumstance worthy of death in California. The trial endured for seven long months, with the jury deliberating for five stretched weeks. I was found guilty. The jury rejected the financial gain allegation, but found true the ambiguous charge of lying-in-wait (because I was driving the car). For that, I now sit in a concrete box sentenced to life without the possibility of parole for the last twenty-one years with no hope of ever being released.

At the conclusion of the penalty phase of the trial, which gives the jury the option of voting for life or death, the panel of twelve voted against having me put to death. I sense they were attempting to be sympathetic after hearing a company of character witnesses testify that I had lived a relatively trouble-free life. Still, while I was relieved to have my life spared, it was not lost on me that my wife and unborn child were gone forever, and my daughter will never again be held by her mother. Not to mention, I am to blame. I must live with that for the rest of my life.

Furthermore, I was betwixed within the finality of a sentence - to be forever lived out in hell's clutches; and though I was spared from death, I lost the right to all of the statutory protections that come with a death sentence. With life without the possibility of parole, absent are the automatic appeals and the close scrutiny that is guaranteed with a death sentence, though incapacitating us for the rest of our natural lives is every bit as serious. To subsist under a life without the possibility of parole sentence could still classify one as a dead man walking - though excruciatingly slower.

Strictly interpreting my case by statute, it was the very technical mistake of driving the car that made the deference between twenty-five years with a possibility to parole and life without the possibility of parole. It was not until recently that research led me to learn that it was the savvy (and sadistic) political maneuvering of the CCPOA that created this snare for me, as well as thousands of others. Crime Victims United (CVU), funded primarily by the CCVPOA, helped sponsor the growing definition of 
California's special circumstance laws in 1982 and 1990, respectively. ${ }^{4}$ In a sense one could say lifers, and all prisoners for that matter, are political prisoners. Political prisoners, not for their conscious, subversive or political ideologies, but indispensible pawns in a rapacious political system that sees them as nothing more than exploitive fodder.

For instance, there is a distinct difference between sincere victims of crime, who want common sense adjustments to the system that not only brings about healing, but also effectively contribute to prevention. Murder Victim Families for Reconciliation (MVFR) and the restorative justice collective is a perfect example. MVFR believes in and strives for reconciliation, a process that involves positively influencing the delinquent mind. They believe in bringing people together, fostering understanding and nurturing forgiveness, healing and closure (Wright, 1998).

If I were a victim, I would want criminals to know how I feel; I would want prisoners to understand what their actions put me and my family through. I would therefore demand that, at the very least, prisons offer some type of victim orientation; videos that capture the various realities and adverse circumstances victims suffer - the financial loss, the sentimental value of items stolen, the temporary or permanent absence of a loved one and the effects of that on the family. And knowing that the majority of prisoners are undereducated, I would demand that they be educated with time off for their achievements. This model creates the incentive and motivation necessary for success, as opposed to the usual model of force, which only serves to provoke resistance and rebellion.

Instead, we have very powerful professional victim groups such as the Doris Tate Crime Victims Bureau (DTCVB) in California, that receives 85 percent of its funding from...guess who? You guessed it, the CCPOA. The DTCVB strives for nothing less than total deprivation, punishment and suffering. This short-sighted approach as a prison model only exacerbates the problem of crime by perpetuating ignorance, the enemy of mankind, idleness, that invites its own dark consequences, all of which amount to pure, unadulterated bitterness, increased individual aggression and, in worse case scenarios, wanton violence (KTLA-5 News, 2010).

It is this manner in which prisons become a self-fulfilling prophecy. Prisoners find themselves in adverse circumstances that are all but predictable; circumstances for which they did not design, and like stressed and repressed animals in a zoo, many finally lash out - at each other and at 
staff. The guards then herald ever louder that the "animals" are incorrigible - they cannot be redeemed or saved. Under the banner of "victims" through CVU and the DTCVB the guards lobby at the top for tougher laws and pile up rules violation reports at the bottom - on the prison compounds.

A problem for taxpayers, and the state, is the incredible stress the costs of these inordinate sentences wreak on other public services under the guise of public safety. As Joseph Cassily, former president of the National District Attorneys Association, told USA Today, long prison terms are a "huge drain on resources" (Johnson, 2009). Cassily is not alone in his assessment, prison reformer Susan Nagelsen (2006) writes that the "growing rate of geriatric prisoners is a looming threat to state expenditures. With elongated sentences, strictly for retributive purposes, not for the more effective rehabilitative process, prisoners are spending longer and longer sentences at state expense, and this population is growing at a rate of ten percent annually".

In the decade between 1984 and 1994 the California prison budget ballooned from $\$ 728$ million to $\$ 3.1$ billion. Today it oscillates between $\$ 10$ to $\$ 11$ billion, not including annual cost overruns (Domanick, 2004). The Centers for Disease Control in Atlanta, Georgia, estimates an annual cost of $\$ 70,000$, or nearly triple that for younger incarcerated men and women, to treat inevitable geriatric-related conditions and diseases (Koch, 2011). At the outset of proposals for such stretched sentences were prudent fiscal warnings that went unheeded.

Now eviscerated are the days when I could run around the prison exercise yard at twenty-three years of age for two hours straight. The challenge to contain my hereditary high blood pressure was rather effortless, particularly when exercise yard hours were consistent during the good budget years. These days yard time is limited and sporadic at best. The right of regular exercise has bees seemingly whittled down to a whim. And these eight-bytwelve concrete cans we're stuffed in were not designed for exercising, only warehousing. The quarters are so crammed that not even yoga's simple sun salutation postures can be completed without metal or concrete obstruction.

Advanced age after twenty-one years in, along with more frequent lockdowns due to staff shortages, and more idle time for fellow prisoners to cause lockdowns, have made the challenge more formidable. Concrete and steel bunks lend to inevitable backaches. The inherent constant stress of prison frays the nerves, raises cortisol levels, which in turn eat away 
at the circulatory system. Add to the natural inescapable depression that accompanies a hopeless sentence and health problems are compounded with mental health issues. Just this week my new blood pressure pills caused a severe ringing in my ears, which will more than likely require a battery of tests before an alternative medication can be prescribed.

The prison diet, alone, is mortal. Almost everything is served from a can, or is otherwise processed, which translates into high-sodium meals laden with PCBs (polychlorinated biphenyl: any of several compounds that are poisonous environmental pollutants which tend to accumulate in animal tissue) certain to kill over consistent and prolonged consumption (ibid).

Local prison policies also cause prisoners' health to decline and health care costs to balloon. Pruno, otherwise known as prisoner-manufactured alcohol, is a popular substance among addicted imbibers. Pruno is easily made from fruit but can be composed of anything which can cause fermentation: rice, potatoes, corn, you name it. Yet, in comparison to the general population, the super sippers are a rare minority. However, that fact does not restrain the powers that be from virtually eliminating fresh fruit from the menu. I have not seen an orange or tomato in over five years. Such policies counter medical wisdom like that of David L. Katz, MD, who recommends men over forty consume at least ten servings of fresh fruit daily (Brant, 2011). Mass punishment is a penological way of course which makes the guards' job easier and the strategy prevails under often-cited claims of "safety and security".

The above only touches the surface as to why the sentence of life without the possibility of parole is another form of death penalty, and offers a graphic elucidation as to the myriad reasons other civilized nations abhor such sentences. Then again, America, unlike other industrialized countries, also continues to cling tightly to the ultimate and most irreversible of punishments.

Again, on yet another occasion to critique misdirected U.S. penal policies, Justice Kennedy is not short on brash criticisms of his homeland's penal policies: "It's true that a death sentence is unique in its severity and irrevocability, yet life without the possibility of parole sentences share some common characteristics with death that are shared by no other sentences". Kennedy emphasized that "[1]ife without the possibility of parole deprives the convict of the most basic liberties without giving hope" (ibid). The sagacious jurists speaks with much insight, for indeed, those serving life without the possibility of parole may be placed in the general population, 
but these men, women and children are prohibited from earning their way to lower level prisons for good behaviour. Yet, like most lifers, those with life without the possibility of parole are by far some of the most behaved prisoners in the system. Still, California, arguably one of the worst prison systems in all of the United States, correspondingly owns the highest suicide rate in the nation (USA Today, 2010). My guess would be that many of those who attempt or succeed at suicide are lifers, the most hopeless of prisoners.

Those sentenced to life without the possibility of parole need not wait until their forties to crash into the wall of mid-life crisis. The wall slams face first into its victims early on as they discover how very restrictive these excessive sentences are compared to others who have murdered and can still look forward to a future, no matter how distant that future promises to be.

It's been a long journey. I grew my first beard behind bars. I learned that my natural hair pattern flows to the right in the Los Angeles County Jail when I was forced to cut my hair low. While stuffed headfirst into a four-man cell in the county jail, I discovered I had a forte for writing. Since those early days of self-discovery in my faded youth, I have taught myself Spanish. I have also taught myself to type by sneaking on the clerks' typewriters during their breaks, and I have earned a paralegal certificate through correspondence. My first nationally published article was printed by the Christian Science Monitor, "My Shawshank Redemption" (Williams, 2008) and my first book publishing experience came a year later with Looking in on Lockdown: A Private Diary for the Public (Williams, 2010). Though frowned upon by my keepers, I have also taught myself to operate various computer programs, formed my own writing class to instruct, and am within a few short months of earning as associate of arts degree in Seminary through a local college.

At age forty-four I am now anxiety ridden by the dark unknown future. While pleased with some of my accomplishments, I cannot help but be cynical: "For what? What good will it do anyone in here?" Those are the bad days and are far outnumbered by the good days, but walking the opposite way of $\mathrm{Oz}$ is no piece of cake. Over the years I have witnessed a mass of violence. I have seen prisoners assault, stab and viciously cut other prisoners. I have seen guards brutally baton, kick and punch prisoners and even fatally shoot my peers. It is a hard mix to digest.

I have seen some of my long-term peers literally lose it. Some progressively became anti-social. They refuse to attend social gatherings, they stop going to the yard or if they do go, they sit off in a far corner and 
silently stare off into the hinterland hovering some place over the abyss. A place only they can see, a world that exists only in their mind. Fred does that, on the few days he comes out. Will tried to commit suicide, along with many others, too many others in fact. They are the fortunate ones, the ones who fail. There are too many who have succeeded.

To counter this dark twisting path I requested to see Dr. Organibu, the facility psychiatrist. Tall, bald and very dark complexioned, Dr. Organibu, with his contrasting bright smile, invited me into his small well-lit office. Nervous, I exploded into jabber: 'I'm not crazy, you know. I'm just here because I have some things on my mind... Nice day isn't it?" The doctors smile persisted as he silently analyzed me.

With a hand gesture he beckoned me to sit in the padded seat in front of his desk. I began the session describing my observations of others who had lost it. I explained that I have been in for twenty-one years and was concerned about my own mental health. I told the doctor that I study a lot and have some limited knowledge and that draws people to me. Plus, I am an optimist and people draw from that. At times I feel bombarded. People dump their problems on me and are constantly at me for one thing or another. I explained that I do not mind helping people, but sometimes I need a break. So I avoid yard and dayroom, just like Fred. When I thought about that it scared me. I asked the doctor if I was in trouble. He asked if I get visits from family and talk with them over the phone. I said, "Yes". He then asked if I have withdrawn from them. I said, "No". At that point the doctor assured me that I am normal.

He then explained that I am in a toxic environment and relationships in prison tend to be toxic. Dr. Organibu explained that normally people compartmentalize their situations as a way to cope. He shared the example of a guy who shares the everyday stresses of work the best way he can. The guy gets off work and puts on a new mindset for home. It breaks up the day by compartmentalizing it. It helps him cope by separating the various roles he must play at each juncture of his day. But prison is not like that he explained. There are no breaks and the human mind was not designed for that. So he assured me that my alternative active and aggressive approach is healthy.

Dr. Organibu then asked how I deal with work. I explained that there was a power struggle going on between the computer department and custody. The computer department is prohibiting us from having the Excel program, a program that computes, while custody likes the work product better with 
Excel. The computer department is winning, yet custody wants the same quality of work in spite of the confiscation. I told the doctor that I had adopted the attitude that I can only work with the tools I am given to work with. The doctor smiled and told me that is a good strategy. In the end he said I am well, considering my environment.

Kenneth E. Hartman is another man sentenced to life without the possibility of parole as a youth after he killed a man during a fist fight in a drug-fuelled, alcoholic stupor that earned him the eternal sentence (Hartman, 2009). For Hartman the technical element that earned him life without the eligibility of parole was that he took his victim's wallet and maliciously threw it on the roof. It was that sole act that separated his crime from say, Robert Jenkins, a man principally sentenced to twenty-five years to life for the mortal shooting of one person and the attempted murder of another. ${ }^{5}$ Jenkins can earn his way out prison if he works hard enough, Hartman cannot.

Reviewing the circumstances - mitigating and aggravating - I would think that shooting a person to death and the deliberate attempt to kill another would garner a greater punishment than the weapon-less killing of a person in a street fight. Moreover, Hartman was drunk, certainly a mitigating circumstance, though I am not arguing his drunkenness was an excuse. On one hand, Jenkins' state of mind was without question malicious, for he sought to kill two people - he simply failed. And for his failure Jenkins was rewarded, he may see the light of day. On the other hand, Hartman remains incarcerated after nearly thirty consecutive years in prison, and a spotless disciplinary record that spans over twenty years. Hartman, I can say with all sincerity, is possessed by an altruistic spirit that has contributed more to curb prison violence than any prisoner I know.

Unfortunately, Hartman could very well die in prison, but until that day he could just possibly break the state in medical costs. A few years ago Hartman was diagnosed with Hepatitis $\mathrm{C}$, a prevalent ailment in prison that affects the liver. It is most often contracted through needle sharing. After a series of treatments, the disease was brought under control. Not long after, he contracted Valley Fever, another prevalent ailment in prison. Apparently Hartman inhaled the fungus, which lies dormant in the soil in many remote areas. Valley Fever knocked Hartman to his knees. He was again subjected to a battery of costly, debilitating treatments before his health improved.

Hartman's latest challenge is his heart with the hardening of his left ventricle. As the doctors monitor his situation and figure out Hartman's 
options, he has been placed on five different medications. One of those medications is called Plavix, which reportedly cost $\$ 400.00$ a month. Hartman is not alone, as cited above. There are thousands of geriatric prisoners who have practically grown up in prison setting an historic, but ignoble precedent in American history.

Critics complain that people who have made some of the worst mistakes, like Hartman, should just be allowed to die in prison. Yet that stance is not only at odds with the ideals of America, but is also as immoral as the minds of the murderers who are the subject of the criticism. It is little understood that prisoners are afforded such protections because prisoners are one of the most vulnerable citizen classes in the nation. Prisoners must rely on the guards to provide everything pertaining to life: food, medicine, showers, clothes. Without such protections and at least the appearance of value for human life, America would be no better than the rogue nations we accuse of violating human rights abroad.

Trevielle Craig was yet another man convicted of an offence resulting in the extraordinary sentence of life without the possibility of parole. In the aftermath of the Rodney King riots, when South Central Los Angeles erupted into mass violence in response to the not guilty verdict of four white police officers who were filmed mercilessly beating King, Craig got caught up in the contagion of chaos that had spread its malignancy to North Hollywood, California. Craig was involved in a fistfight with another man who died eight months later. The victim descended into a coma the night of the fight as a result of a single blow to the head. Craig cooperated with police, his story was corroborated by the physical evidence, yet he ended up eternally chained to a sentence of life without the possibility of parole. ${ }^{6}$

It is worth repeating that life without the possibility of parole was originally introduced as an alternative to the death penalty for serial killers and people so psychologically deranged that there was never any possibility of redemption. What I find most astounding is the absurd assertion that prisoners (implying all) are "hardened" or "incorrigible". Indeed, whenever the majority of people fail in any system, it becomes apparent that the failures are that of the system, not the people. Again, the trend has been for society to overlook the failing system and punish the hapless prisoner with evermore excruciating sentences - though the prisoners are not the ones who determine how much or of what quality of rehabilitation they are exposed to, if any at all. 
The prudent must ask why prisoners cannot be reformed. Or can they? We see a host of troubled celebrities here of late ordered to rehabilitation by the same criminal justice system that sentences scores of faceless poor to prison. Yet celebrities such as actor Tom Sizemore, singer Lionel Richie's daughter Nicole, NFL sports star Michael Vick and former child actor Todd Bridges have all committed felonious acts. ${ }^{7}$ And all seemed to have been cured - rehabilitated after the fact.

So the question remains, why can the entities we call "corrections" not do the same? Is it possible that guards' training does not include rehabilitation? Could it be that a violent system lorded by guards trained primarily in the use of force, not human behaviour, is the wrong approach, the wrong model? Could it be that the Prison Industrial Complex is actually denying rehabilitation for its own job security? These are questions that demand answers during this national crisis of prison overcrowding and atrocious recidivism rates. Because if prisons can rehabilitate people, like the military and non-custodial institutions, then life without the possibility of parole is completely unnecessary for a vast number of prisoners.

The reality is that people are incredibly malleable. The military has an extraordinary record of "reforming" people. In fact, when it was U.S. policy to send people accused of crimes to the military, the success rate for the military was nearly the complete opposite of what our prison failure rate is today. According to a wide ranging list of sources, statistics show that for lifers reformation comes almost automatic. Age, experience and maturity tend to shed the criminal mindset from most lifers. Not only are lifers historically the most well-behaved in the prison system, they are also the least likely to return to prison once released (CDCR, 2009, p. 11). ${ }^{8}$ In fact, according to the California Department of Corrections and Rehabilitation's own website, rehabilitation programs such as the California Prison Industry Authority are impressively successful. "CALPIA's preapprenticeship program is a leading example of how effective rehabilitation reduces recidivism", said Kathy Jett, spokeswoman for CDCR. CDCR's research shows that participants of CALPIA have a 25 percent lower rate of recidivism than the general population (CDCR Today, 2011).

On the other hand, it has long been forgotten why America adopted the Quaker's version of justice called "penitentiaries". The root word is penitent. The objective was to subject the miscreant to a solitary cell with a bible and let him repent, that is, to come to a place of penitence and reform 
himself. While the results of that experiment have left a murky history, it is obvious that the very aim and ideal of the Quakers has been corrupted and subverted. As mentioned earlier, profit and political motives have filled already overcrowded cells, prohibiting any one prisoner from "finding himself" in the chaotic ruckus of the prison environment we have today. The modern American prison atmosphere offers prisoners nothing more than an idle, purposeless setting to be physically warehoused and mentally stagnate. Again, how can such a model contribute to public safety?

As is often cited by prison reformers, America comprises just 5 percent of the world population, but imprisons 25 percent of the world's prisoners. While it is obvious that the United States is at odds with most of the world in its approach to punishment and human reform, Vernor Muñoz, Special Rapporteur on the Right to Education appointed in 2008 by a body of the United Nations, had this to say about modern criminal justice, prisoners and education: "Opportunities for education should be commonplace in detention, not simply an add-on should resources 'allow' it. It should be aimed at the full development of the whole person requiring, among others, prisoner access to formal and informal education, to literacy programmes, basic education, vocational training, creative, religious and cultural activities, physical education and sport, social education, higher education and library facilities" (Muñoz, 2009, p. 165).

This is what it takes to reform the criminal mind into a law abiding mind. If there is to be any hope in converting the criminal mind, Americans must give prisoners access to the mainstream social activities the majority of indigent prisoners were deprived of in the first place. Indeed, if society refuses to invest in its prisoner-citizens, how can society ever expect to reap any dividends from those so commonly deprived?

During a recent Democratic state attorney general candidate debate, California Assemblyman Ted Lieu points out that six out of ten prisoners are illiterate, yet the California prison system allots a mere two percent of its annual $\$ 9$ billion budget toward rehabilitation programs. Considering that the vast majority of prisoners will eventually be released, that is a backward approach to public safety. ${ }^{9}$ Many politicians forward the myth that it is a waste to lend any rehabilitation to prisoners who will never get out, effectively sealing their 'incorrigibility', and perpetuating the selffulfilling prophecy of violence and failure. Indeed, how can politicians and prison officials claim anyone is incorrigible if they prohibit the very tools that make rehabilitation possible? 
Muñoz (2009, p. 171) further offers the following: "The challenge before us is to create an environment for those who are detained that enables human dignity, capacity and positive change". Society has a choice of what model of prisons it wishes to facilitate and pay for. It should choose the most practical and humane; the very model that offers some hope of at least the possibility of change. That is what makes sense. Once the process of personal reform is claimed by any prisoner and their minimum time is served, a parole board reviews, screens and measures their claim based on the accomplishments and positive behaviour of the prisoner, as documented by officials. For every prisoner trying to convince a sceptical parole board that they have been rehabilitated is in and of itself a formidable challenge.

According to Scott Handleman, an attorney in San Francisco who represents prisoners in parole hearings, there were 31,051 prisoners serving life with parole in California in 2008. Of those lifers 8,815 were beyond their minimum eligibility dates. Of those 6,272 prisoners went before the parole board. A total of 272 prisoners were found suitable for parole dates. Under relatively recent California law, the governor must review parole board recommendations for suitability, imprudently politicizing the process. In 2007, between .01 and .02 percent of those found suitable for release were approved by the governor's review (Cockburn, 2009). This is completely arbitrary. Why even have a parole board if a politician can rescind the findings of the state's purported experts? This makes absolutely no sense.

It is interesting that Charles Manson, the man who stands convicted of ordering the brutal murders of actress Sharon Tate, and others, the man convicted of one of California's most horrific crimes, gets screened by a parole board. Does this make sense? If Manson, with his hate-filled swastikas and continued displays of the most bizarre behaviour can be screened, then why not allow others with a documented history of change the opportunity to be screened? Taxpayers and people of conscience should demand this to at least see if any changes, any growth, any rehabilitation has occurred. Otherwise how else will society ever know? How can taxpayers ever judge a system that refuses to leave any type of record to justify itself?

There are countless men and women who have been incarcerated for decades who are demonstrably reformed and redeemed, who prove the sceptics so very wrong. What I find most interesting here is that neither politicians nor prison guards are experts in human behaviour. If one stops to really think about it, politicians are, well, just politicians. They are, perhaps, 
experts in the art of politicking, but politicians are not psychiatrists, psychologists or criminologists. And this might come as a surprise to some, but nor is the average prison guard trained in these fields. According to my interviews, prison guards are primarily trained in human control through commands and use of force - a euphemism for violence by government officials. The majority of guards possess absolutely no credentials in the sciences of human behaviour.

Where is America's penchant for second chances for cases such as Hartman and Craig, both of which are first-time offenders. Both have performed years of disciplinary-free behaviour. Should a parole board forever be prohibited from reviewing their cases and cases like theirs? Mandatory sentences - the immoral conveyor belt to justice - only cheapens the American justice system. The one-size fits all approach to treating people, particularly in life and death cases, discredits the American brand, shames the moral mainstream and dilutes American ideals of justice.

America sentences and imprisons its citizens with the same callousness it condemns other countries for human rights violations. I believe $\mathrm{Mr}$. Muñoz, representing the United Nations, makes his point and my point indistinguishable with this closing statement of his report: "Deprivation of liberty should be a measure of last resort. Given the considerable long-term economic, social and physiological consequences of detention on detainees, their families and the community, considerably greater attention should be paid to implementing alternatives to detention for children and adults alike (Muñoz, 2009, p. 173). Makes sense to me.

\section{ENDNOTES}

1 See Coleman et al. v. Schwartzenegger; Plata et al. v. Schwartzenegger; Perez et al. v. Tilton; <www.cdcr.ca.gov/communications/prisonerovercrowding.html>.

Ibid.

Ibid.

4 See Proposition 18 (SB 1878 of the 1997-98 Reg. session) Murder: Special circumstances; Legislation Initiative Amend.; Proposition 7 (SB 155, 1997); Propositions 114 and 115 in 1990; Proposition 196 enacted by the voters in 1996, explaining the number of special circumstances)

5 People v. Jenkins, 19 Cal. Rptr. 3d 386 (the name of Robert is fictional).

6 Treveille Craig, CDCR\# H98882; Superior Court No. LA012897, Van Nuys Superior Court: RT 2, p. 462 (Dr. Sathyavagiswaran's testimony); RT 1, p. 193 (Confession 
tapes); RT 1, p. 8 (Craig only stuck victim once); RT 1, p. 17 (Craig co-operated with police).

7 See Welkos, Robert W. (2005) "Tom Sizemore Gets Jail Term for Violating Probation", Los Angeles Times - March 25; Hunter, Holly (2005) "Tom Sizemore Failed Seven Drug Tests", Celebrity Justice, KTTV-11 Fox - February 25; CBS (2001) "Nicole Riche Turned Her Life Around", The Talk - January 4; Atlanta Journal Constitution (2011) "Animal Rights Group Wants [Michael] Vick's House" - February 8; ABC (2011) "Todd Bridges Changes Course”, The View - March 15.

833 percent of the California prison population emanates from Los Angeles County.

9 KABC (2010) "Democratic State Attorney General Candidate Debate" - May 23.

\section{REFERENCES}

Appleton, Catherine and Bent Grøver (2007) "The Pros and Cons of Life without the Possibility of Parole", British Journal of Criminology, 47: 597-615.

Brant, John (2011) "Look Great at Any Age”, Men's Health, p. 146 - March 30.

California Department of Corrections and Rehabilitation [CDCR] (2009) Corrections Moving Forward, p. 11.

California Rehabilitation Oversight Board (2011) Amended Bi-Annual Report, p. 1 March 15.

CDCR Today (2011) "California Prison Industry Authority (CALPIA) Provides Economic Benefit of $\$ 497$ Million for State" - January 5. Retrieved from $<$ http://cdcrtoday.blogspot.com/2011/01/california-prison-industry-authority.html $>$.

Cockburn, Alexander (2009) "Dead Souls", Counterpunch - May 8-10.

Domanick, Joe (2004) Cruel Justice: Three Strikes and the Politics of Crime in America's Golden State, Los Angeles: University of California Press.

Families to Amend California's Three Strikes (2011) "3-Strikes Law in a Nutshell”. Retrieved from <http://facts1.live.radicaldesigns.org/article.php?list=type\&type $=12>$.

Hartman, Kenneth E. (2009) Mother California: A Story of Redemption Behind Bars, Atlas $-<$ www.kennethehartman.com $>$.

Johnson, Kevin (2010) “As Violent Crime Drops, Gang Ranks Swell 25 percent”, USA Today - November 1.

Johnson, Kevin (2009) "Report Pushes Abolishing Life Without the Possibility of Parole Sentences", USA Today - July 23.

Koch, Wendy (2011) "Study: Eating Fresh Food Lowers BPA in Systems", USA Today, p. $15 \mathrm{~A}$ - March 30 .

KTLA News (2010) "King Family Vows to Fight for New Law" - May 3.

Muñoz, Vernor (2009) "The Right to Education of Prisoners in Detention: Summary of Report Presented to the UN Human Rights Committee in June", Journal of Prisoners on Prisons, 18(1\&2): 164-174.

Nagelsen, Susan (2006) Journal of Prisoners on Prisons, 14(2): v-x.

Nellis, Ashley and Ryan S. King (2009) "No Exit: The Expanding Use of Life Sentences in America", Washington (D.C.): The Sentencing Project.

New York Times (2010) "Justice Kennedy on Prisons" - February 16. 
Moore, Martha T. (2009) "Jobs Lost as States Close Prisons", USA Today-August 18. Papa, Anthony (2010) "My Journey to Reform the Rockefeller Drug Laws", Journal of Prisoners on Prisons, 19(1): 107-110.

Torres, Kristina (2010) "Vote Pits Teachers Against Governor", Atlanta Journal Constitution.

USA Today (2010) "Van der Sloot Disclosure Reverberates" - June 9.

Webb, Jim (2009) "Why We Must Fix Our Prisons", Parade - March 29.

Williams, Carol J. (2010) "Justice Kennedy Laments the State of Prisons in California, U.S.", Los Angeles Times - February 4.

Williams, Dortell (2010) Looking in on Lockdown: A Private Diary for the Public, Concord: Infinity Publishing.

Williams, Dortell (2008) “My Shawshank Redemption”, Christian Science Monitor November 10.

Wright, Paul (1998) “Victims' Rights as a Stalkinghorse for State Repression”, Journal of Prisoners on Prisons, 9(2): 17-22.

Zimring, Franklin E., Gordon Hawkins and Sam Kamin (2001) Punishment and Democracy: Three Strikes and You're Out in California, New York: Oxford University Press.

\section{ABOUT THE AUTHOR}

Dortell Williams has been incarcerated for 21 years consecutively serving a sentence of LWOP. He is self-educated and now teaches others Spanish and Creative Writing. Author of articles appearing in a number of local and national outlets, Williams has recently written a book entitled Looking in on Lockdown: A Private Diary for the Public (Infinity Publishing, 2010). To see more of his work readers can visit www.myspace.com/ aprisonersperspective. Williams is currently seeking books and other resources pertaining to prisons and penal policies in other countries. He can be reached at dortellwilliams@yahoo.com. 